\title{
Effect of cutting fluids application on the cutting temperature and drilling time of mild steel material
}

\author{
C.O. Eze ${ }^{1}$, O.C. Okafor ${ }^{2,}{ }^{*}$, I. E. Ekengwu ${ }^{3}$, O.G. Utu ${ }^{4}$ and H.C. Olisakwe ${ }^{3}$ \\ ${ }^{1}$ Chukwuemeka Odumegwu Ojukwu University, Uli, Anambra State, Nigeria. \\ ${ }^{2}$ Grundtvig Polytechnic, Oba, Anambra State, Nigeria. \\ ${ }^{3}$ Nnamdi Azikiwe University, Awka, Anambra State, Nigeria. \\ ${ }^{4}$ Delta State Polytechnic, Ogwashiuku, Nigeria.
}

Global Journal of Engineering and Technology Advances, 2022, 10(02), 001-008

Publication history: Received on 24 December 2021; revised on 31 January 2022; accepted on 02 February 2022

Article DOI: https://doi.org/10.30574/gjeta.2022.10.2.0029

\begin{abstract}
Heat production associated with every machining operation has a significant effect on the cutting temperature and drilling time. Such effect is mitigated through the application of cutting fluids that would help to conduct off the generated heat actuated by the frictional contact between the tool and workpiece cutting zone. The effects of the vegetable oils (Gmelina oil, Neem oil and Castor oil) and conventional soluble oil on the cutting temperature and drilling time were studied at various spindle speeds, feed rates and cutting speeds. The vegetable oils were extracted from their various seeds using solvent and pressing method. A minimum quantity lubricating (MQL) system was set-up and was used to control the flow of the cutting fluid to the drilling zone of the tool-workpiece interface. A vertical drilling machine having a $20 \mathrm{~mm}$ drill bit size was used to drill a through hole of $40 \mathrm{~mm}$ depth on a mild steel material. During the drilling process, the cutting fluid was applied to the drilling zone using the MQL system and the cutting temperature and drilling time were measured with an infra-red thermometer and a stop watch respectively. The results gotten from the experiment showed that Gmelina oil gave the lowest cutting temperature and drilling time. This was followed by soluble oil, Neem oil and then Castor oil. Under a dry drilling condition, the cutting temperature and drilling time obtained were the highest compared to other cutting fluids applied conditions. Therefore, cutting fluids application reduces the cutting temperature and drilling time and should be employed in industrial operations for the attainment of good machining characteristics.
\end{abstract}

Keywords: Machining; Vegetable oils; Soluble oils; Cutting temperature; Drilling time

\section{Introduction}

Machining operations performed using power driven tools or machines such as: lathe, milling, drilling, pressing machines etc. are always associated with heat dissipation phenomenon. The heat usually emanates from the toolworkpiece zone as a result of the frictional contact between them. The life of the cutting tool and the surface integrity of the workpiece being machined are affected by the dissipated heat resulting from the machining operation. During the machining process, the associated heat of the process raises the temperature of the tool and workpiece which can be mitigated through the application of cutting fluids. Surface integrity of a material as defined by Sultan et al [1] is a superficial and in-depth properties of the surface of an engineering material that affects its performance characteristics during service conditions. These properties are: surface finish, texture, wear resistance, fatigue corrosion, etc. The surface integrity of an engineering material is affected by factors such as: the material type, spindle speed, feed rate, depth of cut, etc.

\footnotetext{
* Corresponding author: OC Okafor; Email: okaforobiorac@gmail.com

Grundtvig Polytechnic, Oba, Anambra State, Nigeria. 
As a result of the negative impact of the conventional cutting fluids on manufacturing cost, human health and environment, research efforts have therefore been directed towards its replacement with vegetable oil cutting fluid that is environmentally friendly. Rao [2] explained that the targeted goal in all the conventional metal-removal operations is geared towards raising productivity and reducing costs by machining at the highest spindle speed and minimum downtime, giving a satisfactory surface integrity of the machined workpiece. The choice of cutting fluid according to Jabba and Usman [3] is as important as the choosing the suitable machine tools, spindle speed and feed rate. The application of cutting fluids as discussed by Abou-El Hossein [4] to the tool-chip interface permits higher cutting speeds, higher feed rate, greater depth of cut, extended tool life, decreased surface roughness, increased dimensional accuracy and reduced power consumption. Based on the preference of vegetable oil over the conventional soluble oil cutting fluids, Charles et al [5] studied the performance of castor oil, neem oil, soluble oil and dry drilling in the drilling operation of mild steel material. Castor oil gave the best surface finish of the mild steel material at a spindle speed of $290 \mathrm{rpm}$ ad feed rate of $0.0985 \mathrm{~mm} / \mathrm{rev}$. Also, Charles et al [6] evaluated the performance of castor, neem and Gmelina oils applied in the drilling operation of mild steel material. Gmelina oil produced the optimal surface integrity of the material at a spindle speed of 290rpm and feed rate of $0.08967 \mathrm{~mm} / \mathrm{rev}$. with a composite desirability of 1.0 .

According to Sales et al [7], the control and knowledge of the temperature of the chip-tool interface are very imperative for the design and accurate selection of a cutting tool for a specific machining application. Trent [8] explained that the maximum temperature developed during machining does not absolutely reside at the cutting edge of the tool, where the compressive and shear stresses are at their highest, but rests majorly on the rake face. Cutting temperatures are used as the basis for ranking cutting fluids and it is determined experimentally and employed as the criterion for comparison. Sales et al [7] studied the cooling ability of cutting fluids and measurement of the chip-tool interface temperatures using the thermocouple technique. The temperature drop of the heated AISI 8640 was measured from $300^{\circ} \mathrm{C}$ up to room temperature using an infra-red thermometer coupled to an AC/DC data acquisition board and a PC. The cutting fluid was applied at the machining zone of the tool-chip interface. The machining tests showed that the application of the fluid with better cooling ability will not always guarantee lower chip-tool interface temperature. Also, Dhar et.al. [9] Conducted experiments to study the influence of Minimum Quantity of Lubrication (MQL) on cutting temperature, chip and dimensional accuracy in turning AISI-1040 steel and concluded that, a mixture of air and soluble oil applied as MQL has been proved to be better comparing with flooding application of soluble oil as cutting fluid.

Therefore, this study was based on investigating the effect of vegetable-based oils and conventional oil on the machining or cutting temperature of mild steel material. The cutting temperature was measured with infra-red thermometer at various spindle speeds. A constant depth of cut of $40 \mathrm{~mm}$ was maintained throughout the drilling process and the cutting fluids were applied to the drilling zone using the minimum quantity lubrication (MQL) system.

\section{Material and methods}

\subsection{Materials}

A mild steel specimen of rectangular shape which this study was centered on determining the effect of cutting fluids application on the cutting temperature of the material was obtained from General Steel Mill, Asaba. The cutting fluids used in this study includes: Castor oil, Neem oil, Gmelina oil and Soluble oil (conventional oil). The vegetable oils (Castor, Neem and Gmelina oils) were all extracted from their various seeds. The various components of the Minimum Quantity Lubrication (MQL) system (compressor, reservoir oil tank, mixing chamber and nozzle) were assembled to operate as a single unit. Other materials employed in this study were: a vertical drilling machine, $20 \mathrm{~mm}$ drill bit size and an infrared digital thermometer.

\subsection{Method}

The cuttings fluids were first extracted from their various seeds using the combination of pressing and solvent extraction methods. The Neem seeds were thoroughly dried to allow for the opening of hull. The extracted seeds were then cleaned in order to remove sands and other impurities before being crushed on a hydraulic pressing machine for the extraction of the Neem oil. This same procedure was employed in extracting oils from Castor and Gmelina seeds. The MQL system was set-up using it various components as shown in figure 1. MQL system regulates the flow of the cutting fluid applied to the drilling zone. 


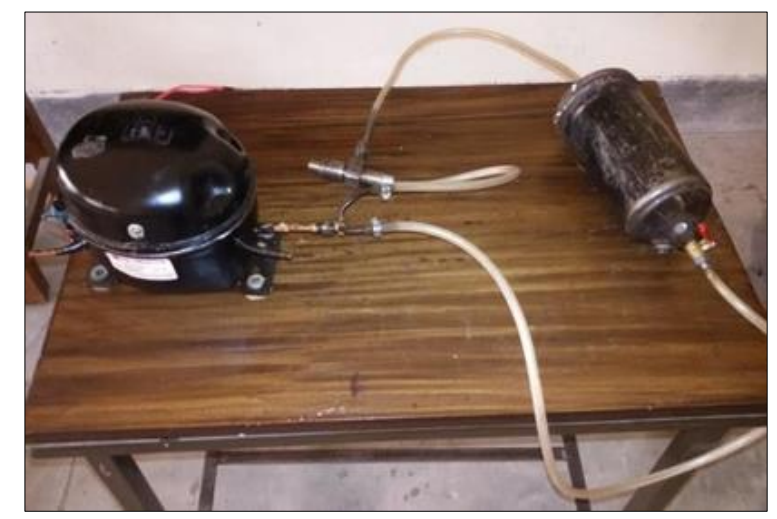

Figure 1 MQL system set-up

The extracted Neem oil was poured into the oil reservoir tank of the MQL system. A 20mm drill bit was installed into the chuck of the vertical drilling and was rigidly fixed on it. A through hole of constant depth of $40 \mathrm{~mm}$ was drilled on the mild steel specimen which was securely fixed on the vertical drilling machine table. During the drilling process, the spindle speed of the vertical drilling machine was varied from 75rpm, 130rpm, 190rpm and 290rpm, and after 5 seconds the cutting fluid (Neem oil) was applied to the drilling zone. The cutting temperature and the drilling time were measured with an infra-red thermometer and a stop watch at each speed of the spindle respectively. Figure 2 shows the application of the cutting fluid (Neem oil) on the drilling zone using the MQL system.

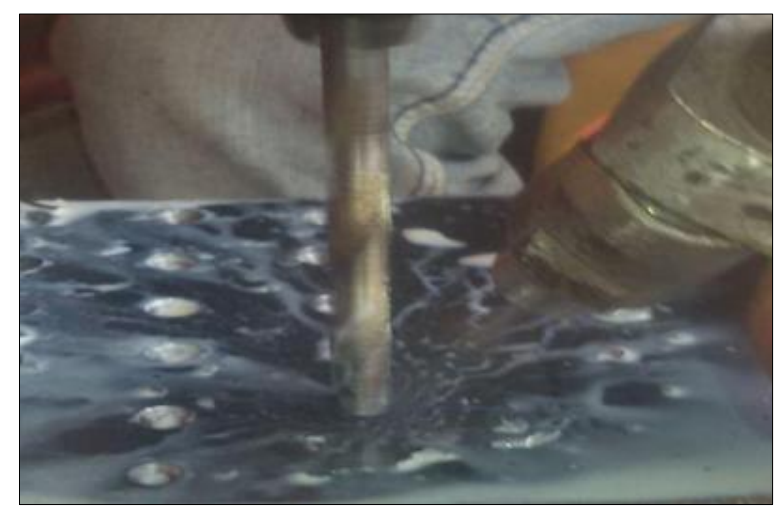

Figure 2 Application of Neem oil on the drilling zone

The procedures were repeated for all the cutting fluids- Castor, Gmelina and Soluble oils. Also, a condition of no fluid application was equally studied in order to decipher the effect of the associated high frictional factor on the cutting temperature of the material. The cutting speeds and feed rates of the drilling operation were evaluated using the formulae expressed by Kurmi and Gupta (2009) as,

Cutting speed, $V=\frac{\pi D N}{1000}$

Drilling time, $\mathrm{T}_{\mathrm{m}}=\frac{\mathrm{L}+0.3 \mathrm{D}}{\text { feed rate } \times \mathrm{N}}$

Where:

$\mathrm{V}=$ cutting speed in $\mathrm{m} / \mathrm{mins}$,

$\mathrm{D}=$ diameter of the drill bit (mm),

$\mathrm{N}=$ spindle speed (rpm),

$\mathrm{T}_{\mathrm{m}}=$ drilling time (mins),

$\mathrm{L}=$ depth of cut $(\mathrm{mm})$. 


\section{Results and discussion}

The application of cutting fluids at the drilling zone of the tool-workpiece interface has a significant effect on the cutting temperature at varying spindle speed condition. Figure 3 shows the graphical plot of cutting temperature against spindle speed variations of the vertical drilling machine.

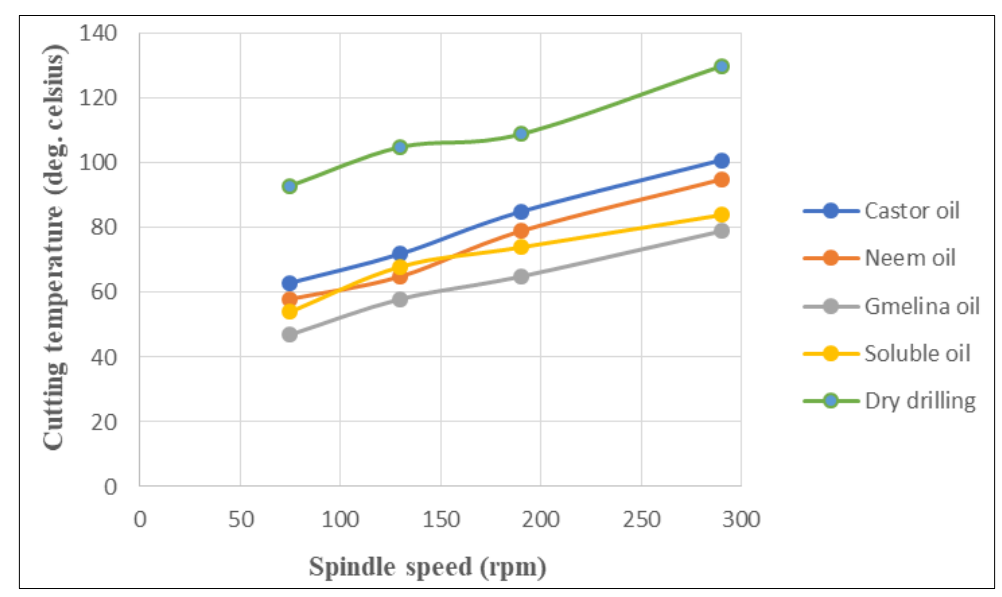

Figure 3 Effect of cutting fluid on cutting temperature at varying spindle speeds

From figure 3, the cutting temperatures could be seen to increase as the spindle speed increases from 75rpm to $290 \mathrm{rpm}$. The cutting temperatures of Gmelina oil was observed to be the lowest from 75rpm to 290rpm spindle speeds. This was followed by soluble oil, Neem oil and then Castor oil. Gmelina oil has a good thermal conductivity value compared to other cutting fluids. Therefore, it best conducts off the generated heat energy resulting from the frictional contact of the tool-workpiece zone than the rest of the fluids. Under dry drilling operation (that is a condition of no cutting fluid application), the cutting temperatures could be seen to be higher than the rest of the operations performed at cutting fluids applied conditions. The cutting temperature was higher because there was no fluid to conduct off the generated heat. This also produces a poor surface finish in the machined workpiece. Also, poor thermal conductivity value of cutting fluids reduces the cutting efficiency of the tool and consequently increases the drilling time. Figure 4 shows the effect of the cutting fluids on the drilling time at varying spindle conditions.

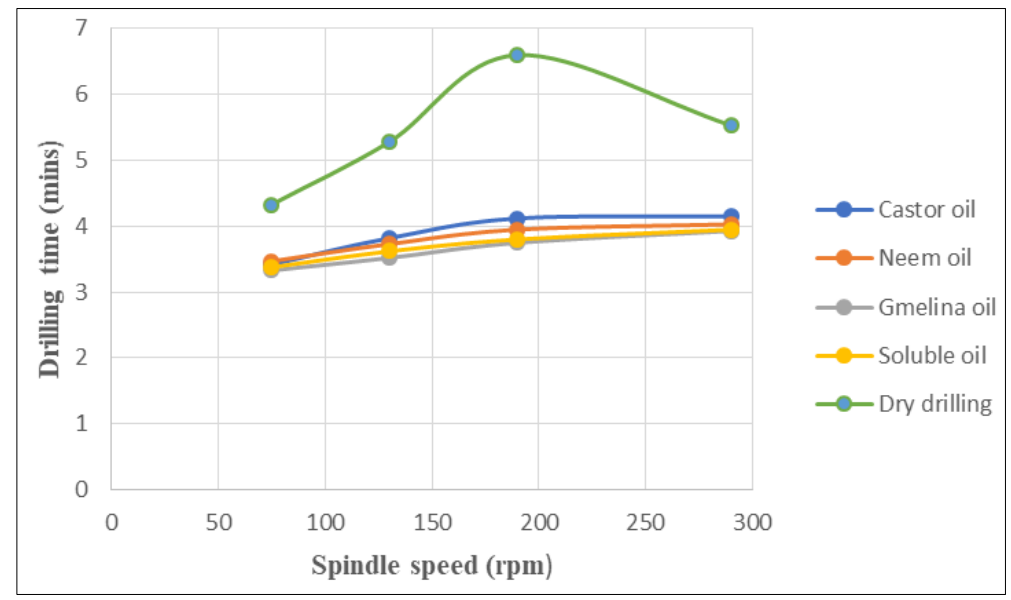

Figure 4 Effect of cutting fluids on drilling time at varying spindle speeds

From figure 4, cutting operation employing Gmelina oil consumed the lowest time, followed by soluble oil, Neem oil and then Castor oil. When no cutting fluid was applied (dry drilling condition), the drilling operation of mild steel material took longer time. This observation could be attributed to the thermal conductivity of the cutting fluids. A cutting fluid with good thermal conductivity enhances the cutting efficiency of the tool which will in turn reduce the drilling time. The cutting temperature also increases as the drilling time increases. Figure 5 depicts this phenomenon. 


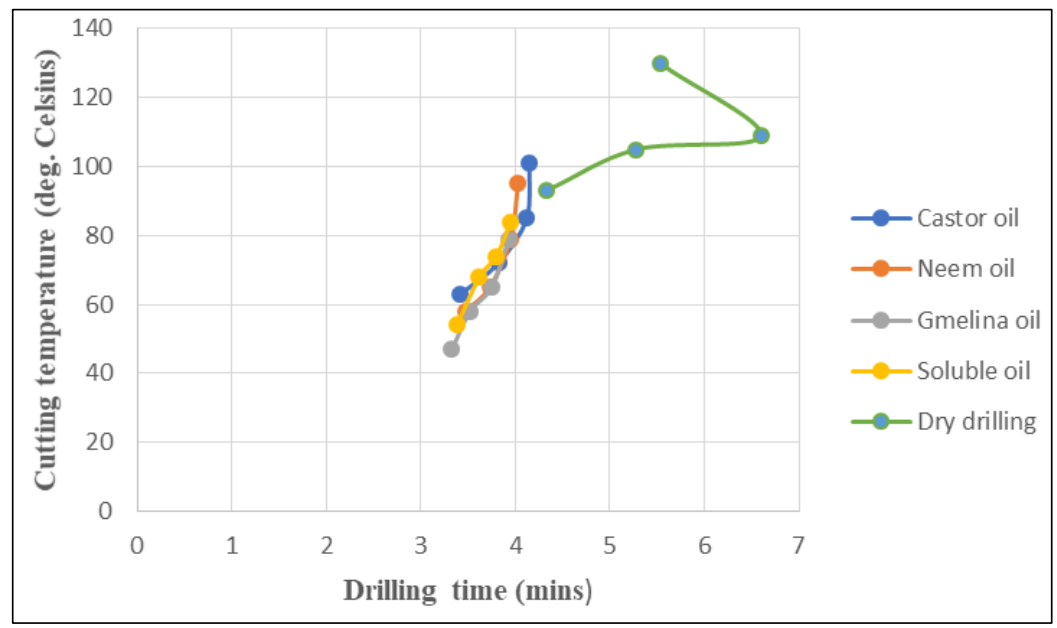

Figure 5 Effect cutting fluids on the cutting temperature and drilling time

From figure 5, the cutting temperature and drilling time could be seen to be affected by the application of cutting fluids. Cutting operation employing Gmelina oil as the cutting fluid exhibited the lowest cutting temperature and drilling time as shown in figure 5. This behavior was followed by soluble oil, then Neem oil and Castor oil. Dry drilling operation had the highest cutting temperature and drilling time as a result of the associated frictional effect that is accompanied by high heat generation. Figure 6 shows the effect of cutting fluids application on cutting temperature at varying feed rates.

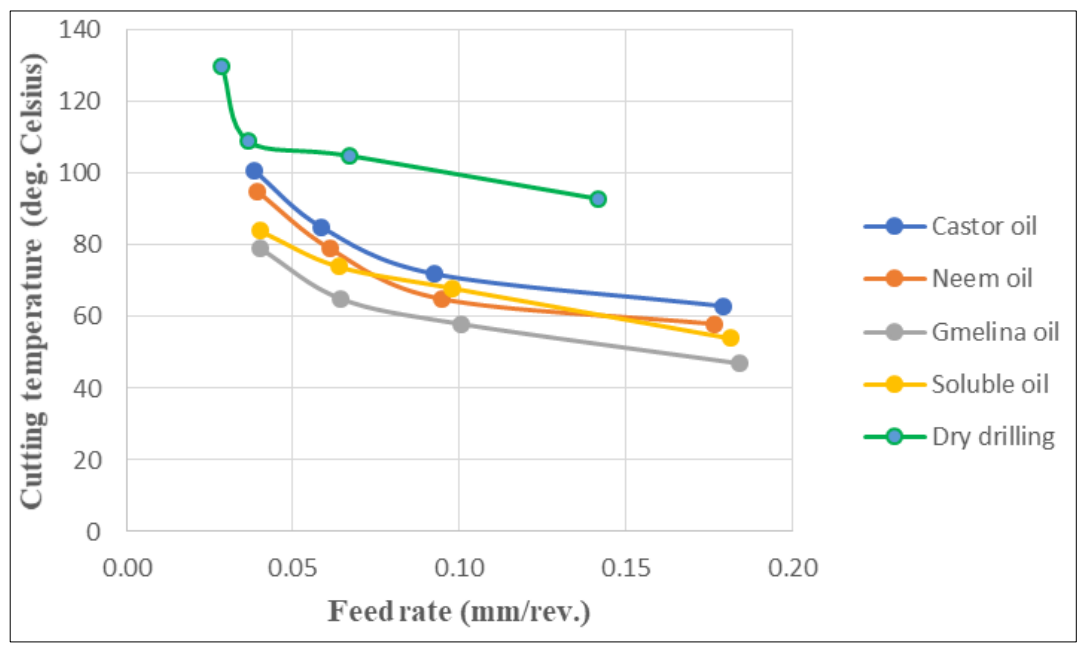

Figure 6 Effect of cutting fluids on cutting temperature at varying feed rates

From figure 6, it could be inferred that at varying feed rates, the cutting temperature of Gmelina oil was lower than the other cutting fluids. This behavior was followed by soluble oil, then Neem oil before Castor oil as portrayed in figure 6 . Also, the cutting temperature of the operation that did not employ any cutting fluid could be seen to be higher than the rest at varying feed rates condition. Furthermore, figures 7, 8 and 9 show the effects of cutting fluid application on drilling time at varying feed rates, on cutting temperature and drilling time at varying cutting speeds conditions respectively. 


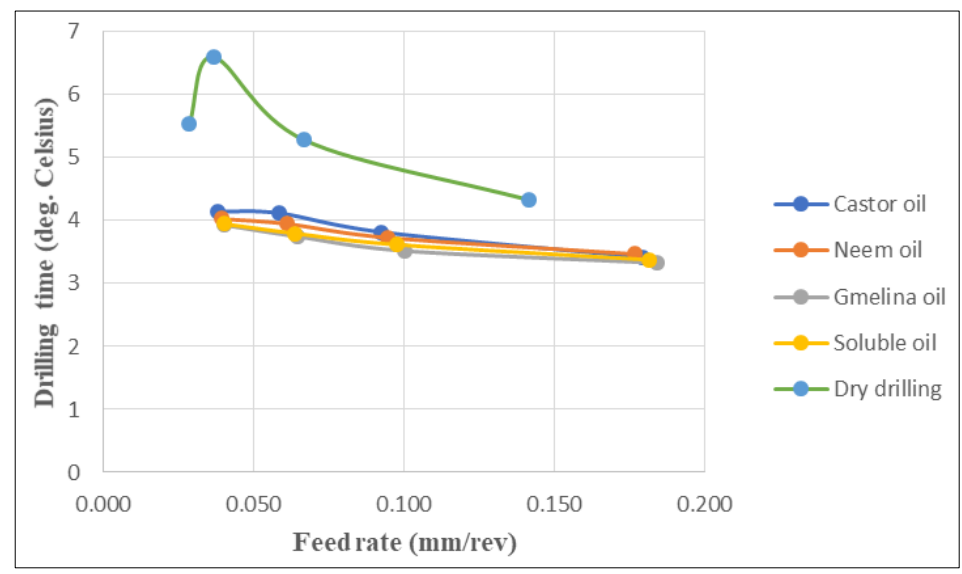

Figure 7 Effect of cutting fluids on drilling time at varying feed rate

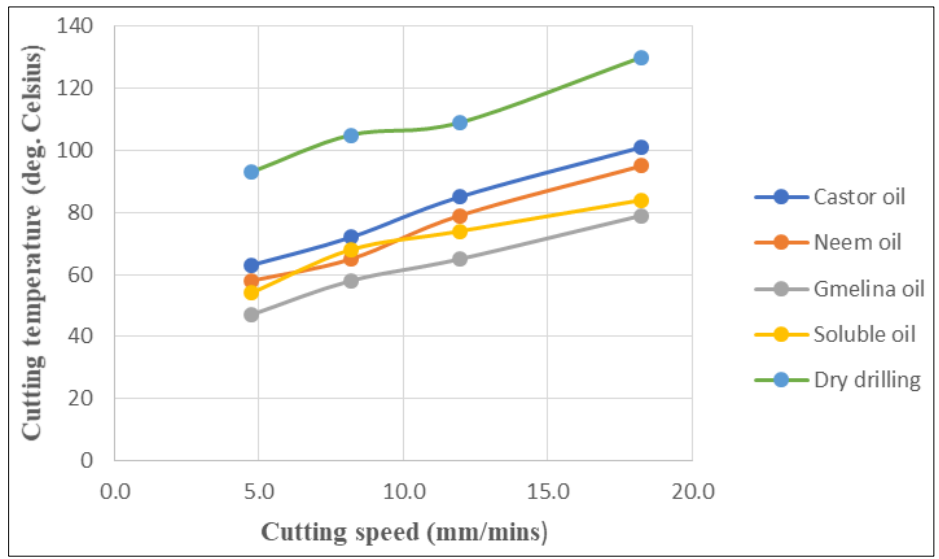

Figure 8 Effect of cutting fluids on cutting temperature at varying cutting speeds

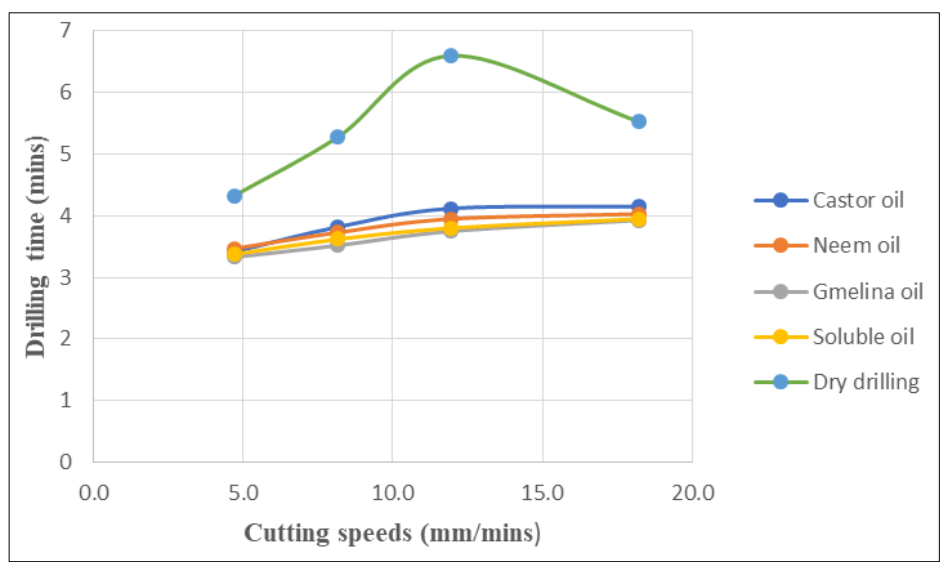

Figure 9 Effect of cutting fluids on drilling time at varying cutting speeds

From figure 7, the drilling time of the cutting operation that used Gmelina oil cutting fluid could be observed to be lower than the rest of the other cutting fluids at varying feed rates condition. Also, the cutting temperature of Gmelina oil applied -operation at varying cutting speeds was lower than the other cutting fluids as depicted figure 8. In addition, Gmelina oil showed to consume the lowest drilling time at varying cutting speed condition when compared to the other 
cutting fluids as shown in figure 9. This observed behavior of Gmelina oil was followed by Soluble oil, Neem oil and then Castor oil. The varying thermal conductivity parameter of the various cutting fluids which defines their heat dissipative ability is responsible for the observed behavioral patterns of the cutting fluids. Gmelina oil has a good thermal conductivity value which enhanced the cutting efficiency of the tool by carrying off the generated heat, thereby maintaining the tool's life and producing good surface finish in the workpiece. Cutting operations under dry condition could be seen to consume more time and raise the cutting temperature at varying feed rates and cutting speeds.

\section{Conclusion}

The effects of cutting fluids on cutting temperature and drilling time at varying spindle speeds, feed rates and cutting speeds were investigated in this study. Cutting operations using Gmelina oil as the cutting fluid consumed the lowest drilling time and had the lowest cutting temperature. This was followed by soluble oil, Neem oil and then Castor oil. Operations involving no cutting fluid application (dry drilling), had the highest cutting temperature and took longer time to drill a through hole on the mild steel material. Therefore, Gmelina oil has better performance characteristics (cutting temperature and drilling time) than the other cutting fluids employed in this study and should be applied majorly to the drilling zone of the tool-workpiece interface.

\section{Compliance with ethical standards}

\section{Acknowledgments}

We appreciate Mr. Harold Ezugwu and all the management staff of Eagle and Hetch (WA) ltd, Enugu, for granting us access to their workshop to run the experiments contained in this study.

\section{Disclosure of conflict of interest}

The authors declare no conflict of interests.

\section{References}

[1] Sultan AZ, Sharif S, Kurniawan D. Examining the effect of various vegetable oil-based cutting fluids on surface integrity in drilling steel- A review, Advanced Materials Research. 2013; 845: 809-813.

[2] Rao PN. Manufacturing technology: Metal cutting and machine tools, Vol. II, 2nd edition; Tata McGraw-Hill Publishing, New Delhi. 2009.

[3] Jabba EU, Usman AB. Effects of using Neem oil as base in cutting fluid for machining operations in Adamawa State Polytechnic, Yola. Journal of Mechanical and Civil Engineering. 2018; 15(2): 16-20.

[4] Abou-El-Hossein KA. Cutting fluid efficiency in end milling of AISI 304 stainless steel. Industrial Lubrication Tribology. 2008; 60(3): 115-120.

[5] Charles OE, Owuama KC, Okafor OC. Performance evaluation of castor oil and neem oil as cutting fluids applied in drilling operations of mild steel, World Journal of Engineering Research and Technology. 2021; 7(4): 90-111.

[6] Charles OE, Onyegirim SN, Owuama KC, Okafor OC. Performance study on some selected vegetable oils used as cutting fluids in the drilling operation of mild steel material, World Journal of Engineering Research and Technology. 2021; 7(5): 1-15.

[7] Sales WF, Guimaraes G, Machado AR, Ezugwu EO. Cooling ability of cutting fluids and measurement of the chiptool interface temperatures. Industrial lubrication and Tribology. 2020; 54(2): 57-68.

[8] Trent EM. Metal Cutting, 3rd Ed., Butterworths-Heinemann Ltd. 1991.

[9] Dhar NR, Islam MW, Islam S, Mithu. The influence of minimum quantity of lubrication (MQL) on cutting temperature, chip and dimensional accuracy in turning AISI-1040 steel, Journal of Material Process Technology. 2009; 171: 93-99. 


\section{Authors Short Biography}

\begin{tabular}{|c|c|}
\hline & $\begin{array}{l}\text { Engr. Onyebuchi Charles Eze obtained his B.ENG degree in Mechanical Engineering and M.ENG } \\
\text { degree in the option of Materials and Metallurgy, from Chukwuemeka Odumegwu Ojukwu } \\
\text { University, Uli, Anambra State. He is currently a PhD Student in the Department of Mechanical } \\
\text { Engineering, Chukwuemeka Odumegwu Ojukwu University, Uli, Anambra State. His research } \\
\text { interest is on material science and metallurgy. }\end{array}$ \\
\hline & $\begin{array}{l}\text { Engr. Obiora C. Okafor is a research and development driven fellow. He is an academic lecturer } \\
\text { at Grundtvig Polytechnic, Oba, Nigeria. Scientech Academy where research and development are } \\
\text { carried out was founded by him. He graduated with a first-class honours degree in both the } \\
\text { bachelor and masters of engineering programmes at Anambra State University, Uli, Nigeria, and } \\
\text { Nnamdi Azikiwe University, Awka, Nigeria respectively. He is a recipient of numerous awards } \\
\text { from various organizations as a result of his academic prowess. He has contributed ten (10) } \\
\text { research papers in the fields of: hydropower, combustion phenomenon, statistical } \\
\text { thermodynamics and strength assurance of welded structures, which were published in } \\
\text { reputable international journals. His research focus is on renewable energy systems, thermo- } \\
\text { fluids, computational fluid dynamics (CFD) and mechanical design. Engr. Obiora C. Okafor is a } \\
\text { registered member of the Institute of Mechanical Engineers (IMECHE), International Association } \\
\text { of Engineers (IAENG)-Mechanical, and International Association of Engineers (IAENG)-Artificial } \\
\text { Intelligence. }\end{array}$ \\
\hline & $\begin{array}{l}\text { Engr. Ekengwu Ignatius Echezona obtained his B.ENG degree in Mechanical Engineering } \\
\text { discipline and M.ENG degree in the area of Design and Manufacturing option, Mechanical } \\
\text { Engineering Department, Chukwuemeka Odumegwu Ojukwu University, Uli, Nigeria. He is an } \\
\text { academic lecturer in the Department of Mechanical Engineering, Nnamdi Azikiwe University, } \\
\text { Awka, Nigeria. He is currently a Ph.D. student at the Federal University of Technology Minna. }\end{array}$ \\
\hline & $\begin{array}{l}\text { Engr. Utu Ochuko Goodluck got his Higher National Diploma (HND) in Welding and Fabrication } \\
\text { Engineering from Petroleum Training Institute, Effurun. He obtained a Postgraduate Diploma } \\
\text { (PGD) in Mechanical Engineering and an M.ENG degree from the same University. He is a lecturer } \\
\text { in the Department of Welding and Fabrication Technology, Delta State Polytechnic, Ogwashiuku. } \\
\text { Currently, he is running his Ph.D. programme in Mechanical Engineering Department, } \\
\text { Chukwuemeka Odumegwu Ojukwu University, Uli. }\end{array}$ \\
\hline & $\begin{array}{l}\text { Engr. Olisakwe Henry Chukwuemeka is a multidisciplinary professional, a graduate of } \\
\text { Chemical Engineering from the Federal Polytechnic, Bida. He obtained his masters degree in } \\
\text { Mechanical Engineering from the Federal University of Agriculture, Makurdi, Benue State. } \\
\text { Currently, he is a Ph.D. student of the same University and formerly, a lecturer and Head of } \\
\text { Mechanical Engineering Department, Nigeria Army Institute of Technology and Environmental } \\
\text { Science (NAITES). Presently, he is a lecturer at Mechanical Engineering Department, Nnamdi } \\
\text { Azikiwe University, Awka. He is a Tribologist, corrosion researcher, a member of Nigeria Society } \\
\text { of Engineers (MNSE), a chartered engineer with COREN, a bio-lubricant consultant with Nigeria } \\
\text { Automotive Council (NAC), and the director of programs for the Institute of Chartered } \\
\text { Information Technology Professionals (ICITP), South Africa. }\end{array}$ \\
\hline
\end{tabular}

